\title{
sciendo
}

\section{GEOPHYSICAL ASSESSMENT OF GROUNDWATER VULNERABILITY TO DIESEL CONTAMINATION AT A TELECOMMUNICATION MAST IN ADEBAYO AREA, ADO-EKITI, SOUTHWESTERN NIGERIA}

\author{
Olaseeni Olayiwola ${ }^{1}$, Fagbemigun Tokunbo' ${ }^{1}$ Ojo Bosede ${ }^{2}$, Amosun Joel $^{1 *}$ and Oyebamiji \\ Ajibola $^{3}$
}

${ }^{1}$ Department of Geophysics, Federal University Oye Ekiti, Nigeria

${ }^{2}$ Department of Applied Geophysics, Federal University of Technology, Akure, Nigeria

${ }^{3}$ Department of Geology, Federal University Oye Ekiti, Nigeria

Received $12^{\text {th }}$ December, 2020, Accepted $1^{\text {st }}$ March, 2021

DOI: 10.2478/ast-2021-0001

*Corresponding author

Joel Amosun E-mail:joelamosun@gmail.com

Tel: $+234-7064821376$

\begin{abstract}
An appraisal of the groundwater vulnerability to contamination risk at Adebayo in Ado-Ekiti, Southwestern Nigeria, was carried out using the electrical resistivity method of geophysical prospecting. Two traverses of length $100 \mathrm{~m}$ each were established for both vertical electrical sounding (VES) and dipole-dipole. Six (6) Vertical Electrical Sounding (VES) and 2-D dipole-dipole profiling techniques of the electrical resistivity method were adopted for the geophysical investigation. The results show variations in resistivity values, depicting four to five geologic layers: the topsoil, laterite, weathered layer, fractured, and the fresh basement. It was observed from the correlation of the geoelectric section and 2-D resistivity image along traverse 1 (TR1) that the groundwater in the study area flows towards the southwestern part, and the fractured basement serves as a migration pathway to the diesel oil in the same direction as groundwater flow. The fractured basement (Well 2) with no lateritic cover has higher resistivity values compare to the fracture zone that was found directly under the mast which was overlain by the laterite. Comparing the resistivity values of Well 1 and 2, Well 2 that was drilled into the fractured basement has more traces of the contaminant than Well 1.
\end{abstract}

Keywords: Geoelectric sections, Groundwater vulnerability, Migration pathway 


\subsection{Introduction}

As popularly acknowledged, life could never occur nor be supported without the presence of water (Obiora and Ajala 2015; Fajana 2020; Khan et al. 2020). The movement and storage of groundwater are influenced by lithology, thickness, and structure of subsurface geological materials (Oladimeji and Oluwaseun 2013; Datta 2020) as it is found within their pores or voids which further exposes groundwater to contamination (Todd 2004; Akinlalu et al., 2017). Groundwater contamination occurs due to some causes such as longterm leaks (underlined petroleum pipes, latrines, and septic tanks), spills at the surface, or waste disposal which is directly washed into groundwater systems (Mogaji et al., 2014; Oguama et al. 2019; Olaseeni et al., 2019; Olaseeni et al., 2020; Omotola et al., 2020). Since aquifers within the Precambrian Basement Complex frequently exist at shallow to near-surface depths, they are vulnerable to surface or near-surface contaminants (Bose et al. 1973; Satpatty and Kanugo 1976; Omosuyi 2010; Agyare et al. 2017; Egbueri 2019). As portable water is not ubiquitous in the subsurface but found only in aquifers that can accumulate and release it, therefore modern geophysical techniques are employed to search for it (Todd 2004; Adiat et al., 2009; Mohamed et al., 2013; Mogaji 2016).

Based on the significant resistivity contrasts that exist between different earth materials, delineation of subsurface geological sequence, geological structures and aquifer units in almost all geological terrains have been successfully executed using the electrical method (Oladapo et al., 2004; Ako et al., 2005; Oladimeji and Oluwaseun 2013; Omosuyi et al., 2008).

The electrical resistivity method measures both lateral and vertical variations in ground resistivity values on the earth's surface (Telford et al., 1990). The true resistivity of the subsurface layer is determined from the apparent resistivity values. Some of the factors that affect resistivity include rock types, rock texture, geological processes, water saturation, permeability, temperature, porosity, and chemistry or salinity of the saturating fluid (Oladimeji and Oluwaseun 2013). The vertical Electrical Sounding (VES) technique is applied in groundwater exploration, environmental and engineering geophysics, and to some extent in mineral exploration (Oladapo et al., 2004). This study, therefore, shows the applicability of the electrical method of geophysical prospecting on the traces of diesel flow observed on two hand-dug wells from a tank leakage at a telecommunication mast in the study area. This study aims to examine the migration pathway of diesel oil leakages on groundwater at Adebayo, in Ado-Ekiti using vertical electrical sounding technique.

\subsection{Experimental}

\section{Description and geology of the study area}

The study area is located at Adebayo, off AB Hotel road, Ado Ekiti, Ekiti State, southwestern Nigeria; and lies within Northings 846150UTM to 846500 UTM and Eastings745950 UTM to 746350 UTM (Fig.1). The study area is accessible through a major road and various footpaths.
The study area is part of the Precambrian Basement Complex rocks of Southwestern Nigeria. Lithological units present within the area and the environs are Migmatite-gneiss, Quartzite, Charnokite, and granite (Fig. 2) while the study area is underlain by Migmatite-gneiss. The rock is generally even-textured and gneissic with mineral aggregates mainly made up of quartz, biotite, and feldspar (Sims and Gable 1967). The superficial deposits are the clay, laterite and fine sands $\left(\mathrm{SiO}_{2}\right)$ which are believed to have been formed from the weathering of the minerals present in the rock.

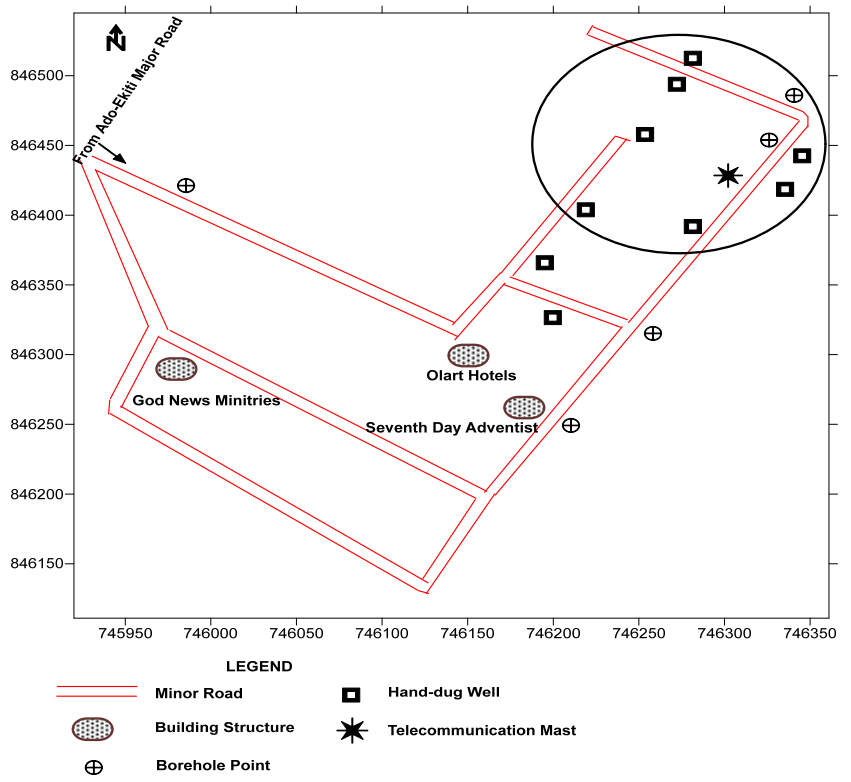

Fig. 1: Base map of the study area

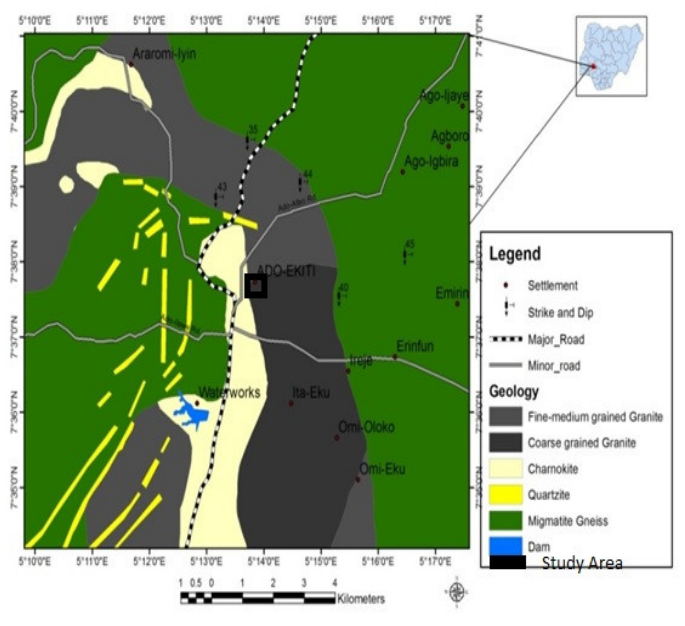

Fig. 2: Geological Map of Ado Ekiti (Modified after Geological Survey of Nigeria Akure sheet 61,2006). 


\section{Data processing}

Six (6) VES measurements were conducted using the Schlumberger array of electrical resistivity method, with a maximum spread length (AB) of $200 \mathrm{~m}$. The data were acquired using ABEM SAS 300 Terrameter. Typically, four electrodes are utilized for resistivity measurements; two current electrodes for passing either direct current or low-frequency alternating current, whilst a different pair of electrodes measure the potential difference between the current electrodes. However, the locations of these electrodes vary with the type of array in use. The apparent resistivity value is determined as the product of the resistance resulting from the potential measurement with an appropriate geometrical factor (Telford et al. 1990).

Using dipole-dipole configuration with a spreading interval of $5 \mathrm{~m}, 2 \mathrm{D}$ electrical resistivity measurements were carried out around the telecommunication mast by establishing two traverses.

VES data were processed and interpreted using partial curve matching and computer-assisted 1-D forward modeling with the aid of WinResist Software (Ademilua and Eluwole, 2013). The 2D data were processed and interpreted using DIPRO software and then presented as pseudosections (Amosun et al., 2018; Olaseeni et al., 2018).

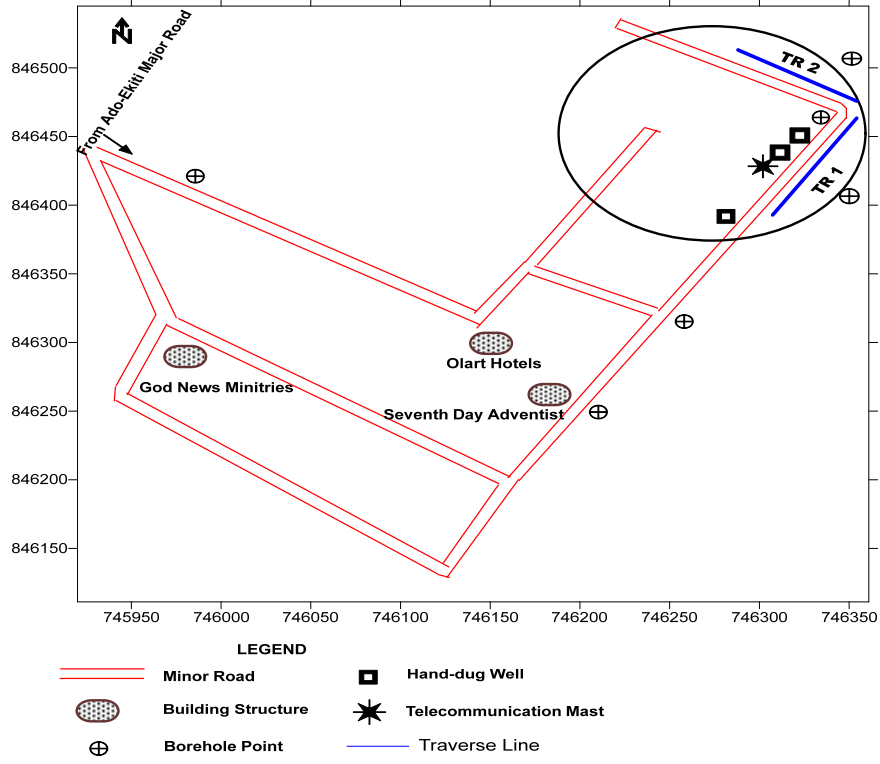

Fig. 3: Geophysical Data Acquisition Map showing the two traverses established.

\subsection{Results and Discussion}

The VES results are presented as VES curve types spanning across KHA, KH, HA, and AA (Figs. $4 \mathrm{a}-\mathrm{d}$ ), a table summarizing the results and lithologies encountered (Table 1), geoelectric section which delineated four to five geologic layers which are the topsoil, laterite, weathered layer, fractured basement and the fresh basement (Fig. 5), while the results of the 2-D horizontal profiling are presented as 2-D resistivity structures (Figs. 6 and 7).

The topsoil resistivity values range from 36 to $750 \Omega \mathrm{m}$ with thickness ranging from 0.5 to $1.4 \mathrm{~m}$. The lateritic layer has resistivity and thickness values in the range of 335 to $603 \Omega \mathrm{m}$, and 1.2 to $3.5 \mathrm{~m}$ respectively. The weathered layer is characterized by resistivity and thickness values in the range of 11 to $344 \Omega \mathrm{m}$, and 0.7 to $3.3 \mathrm{~m}$ respectively. The fractured basement layer has resistivity and thickness values ranging from 66 to $317 \Omega \mathrm{m}$ and 0.8 to $19.5 \mathrm{~m}$ respectively. The fresh basement constitutes the base layer with resistivity values ranging from $1194 \Omega \mathrm{m}$ to infinity. Depth to the rock head varies between $0.5 \mathrm{~m}$ and $20 \mathrm{~m}$.

The weathered layer and fractured basement constitute the aquifer units in the study area. Figure 5 shows two different Wells that were positioned at different distances from the mast and different depths. Well 2 was at a greater depth (of about $12 \mathrm{~m}$ ) than Well 1 which was about $5 \mathrm{~m}$ deep. This means that Well 2 was drilled directly into the fractured basement, which could have been polluted while Well 1 which was closer to the mast fell within the weathered layer. Based on the resistivity values, the weathered layer appeared to be clayey. Since the contaminant migrates in the direction of flow of groundwater, it can be inferred that Well 1 has fewer traces of the contaminant than Well 2.

\section{2-D Resistivity Images}

The 2-D resistivity structure (Fig. 6a-c) along traverse 1 (TR 1) reveals that the area around Well 2 was generally characterized by relatively high resistivity. The 2-D resistivity structure along Traverse 2 (Fig. 7ac) was carried out for control purposes. Figure 8 displays a direct correlation and establishment of relationships between the geoelectric section and the resulting $2 \mathrm{D}$ resistivity image. The mast is located between stations 6 and 7, underneath which, at a depth of more than $5 \mathrm{~m}$, there exists a zone of relatively higher resistivity (Fig. 8). The higher resistivity zone is likely to have been caused by the closeness of the fresh basement to the surface. Well 1 is located between stations 8 and 9 , where a low resistivity band was observed (compared to the zone directly beneath Well 2). This corroborates the earlier inference which suggested that well 1 contained fewer traces of the diesel contaminant. Well 2 falls on station 10 and can be observed to possess a higher resistivity value than Well 1 . This further strengthens the earlier inference from the geoelectric section that Well 2 contains more of the diesel contaminant than Well 1(which would have increased the resistivity around that area). Hence, the migration pathway can be observed from the $2 \mathrm{D}$ resistivity image to be southwesterly.

The 2-D resistivity structure along Traverse 2 did not show any evidence of contamination as revealed by the relative layering of the geoelectric layers in order of increasing resistivity but a basement depression between stations 8-13 was shown. 

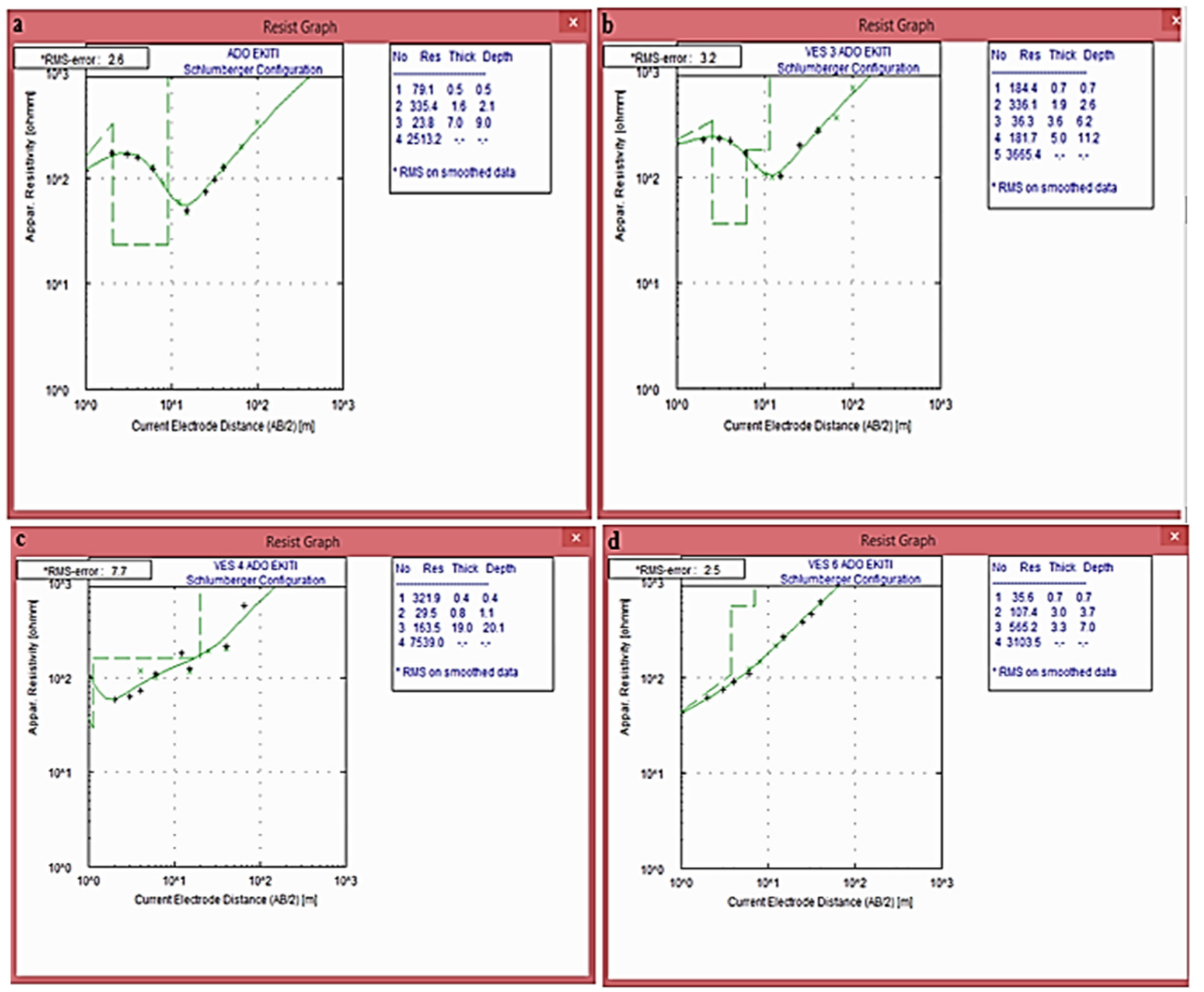

Fig. 4: Typical VES Curve Types (a) KH (b) KHA (c) HA (d) AA from the Study Area
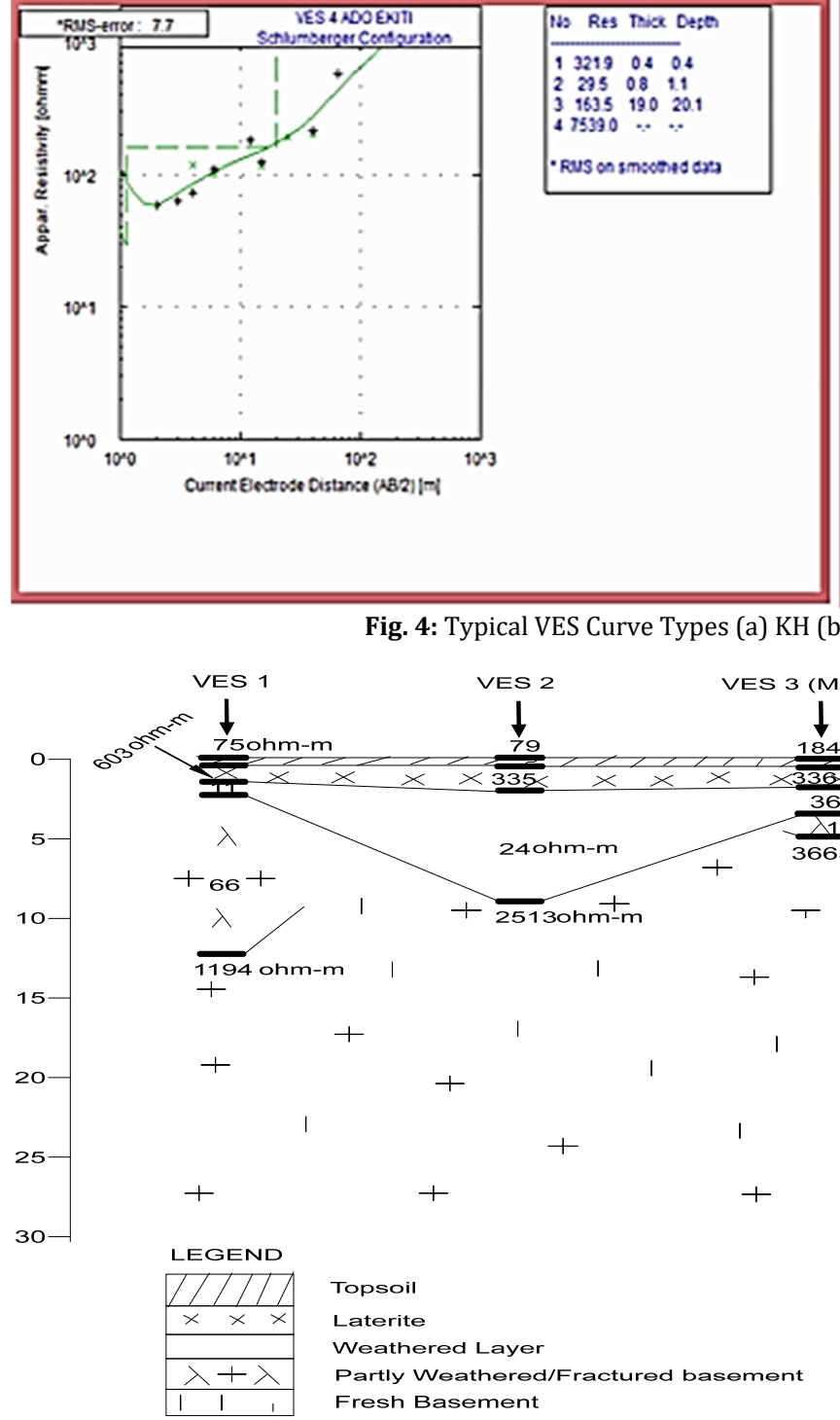

h 
Table 1: VES Results and Lithologic Classification.

\begin{tabular}{|c|c|c|c|c|c|c|}
\hline \multicolumn{2}{|c|}{ Traverse VES No } & \multirow{2}{*}{$\frac{\text { Resistivity }(\Omega \mathbf{m})}{75}$} & \multirow{2}{*}{$\begin{array}{l}\text { Thickness (m) } \\
0.5\end{array}$} & \multirow{2}{*}{$\begin{array}{l}\text { Depth (m) } \\
0.5\end{array}$} & \multirow{2}{*}{$\begin{array}{l}\text { Lithologic Classification } \\
\text { Topsoil }\end{array}$} & \multirow{2}{*}{$\frac{\text { VES Curve Type }}{\text { KHA }}$} \\
\hline 1 & 1 & & & & & \\
\hline & & 603 & 1.1 & 1.6 & Lateritic layer & \\
\hline & & 11 & 0.8 & 2.4 & Weathered layer & \\
\hline & & 66 & 9.9 & 12.3 & Fracture basement & \\
\hline & & 1194 & - & - & Fresh basement & \\
\hline & 2 & 79 & 0.5 & 0.5 & Topsoil & $\mathrm{KH}$ \\
\hline & & 335 & 1.6 & 2.1 & Lateritic layer & \\
\hline & & 24 & 7.0 & 9.0 & Weathered layer & \\
\hline & & 2513 & - & - & Fresh basement & \\
\hline & 3 & 184 & 0.7 & 0.7 & Topsoil & KHA \\
\hline & & 336 & 1.9 & 2.6 & Lateritic layer & \\
\hline & & 36 & 3.6 & 6.2 & Weathered layer & \\
\hline & & 182 & 5.0 & 11.2 & Fracture basement & \\
\hline & & 3665 & - & - & Fresh basement & \\
\hline & 4 & 322 & 0.4 & 0.4 & Topsoil & HA \\
\hline & & 30 & 0.8 & 0.8 & Weathered layer & \\
\hline & & 164 & 19.0 & 20.1 & Fracture basement & \\
\hline & & 7539 & - & - & Fresh basement & \\
\hline & 5 & 72 & 1.4 & 1.4 & Topsoil & $\mathrm{KH}$ \\
\hline & & 344 & 5.9 & 7.3 & Weathered layer & \\
\hline & & 317 & 1.8 & 9.1 & Fracture basement & \\
\hline & & 1712 & - & - & Fresh basement & \\
\hline 2 & 6 & 36 & 0.7 & 0.7 & Topsoil & AA \\
\hline & & 107 & 3.0 & 3.7 & Weathered layer & \\
\hline & & 565 & 3.3 & 7.0 & Fracture basement & \\
\hline & & 3104 & - & - & Fresh basement & \\
\hline
\end{tabular}
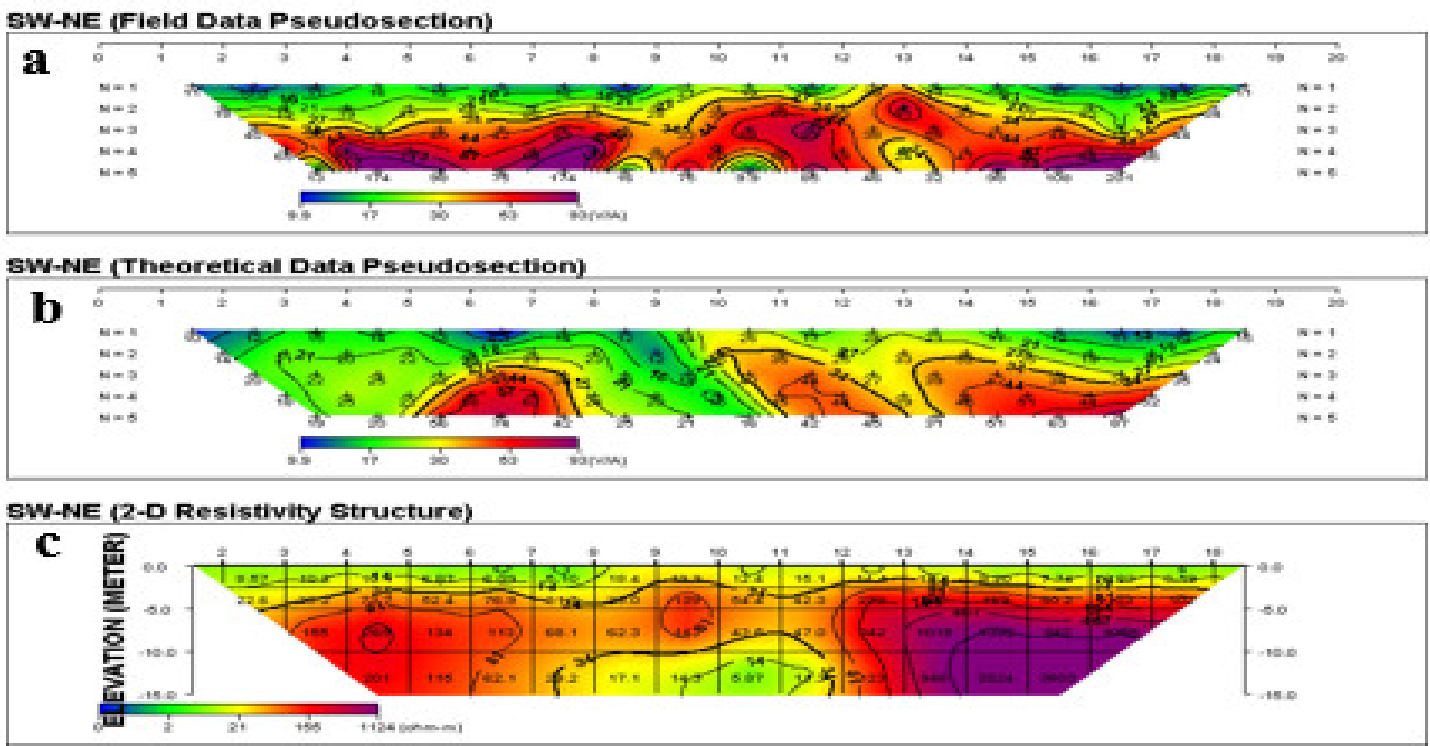

Fig. 6: (a) Field Data Pseudosection (b) Theoretical Data Pseudosection and (c) 2-D Resistivity Structure along Traverse (TR 1) 

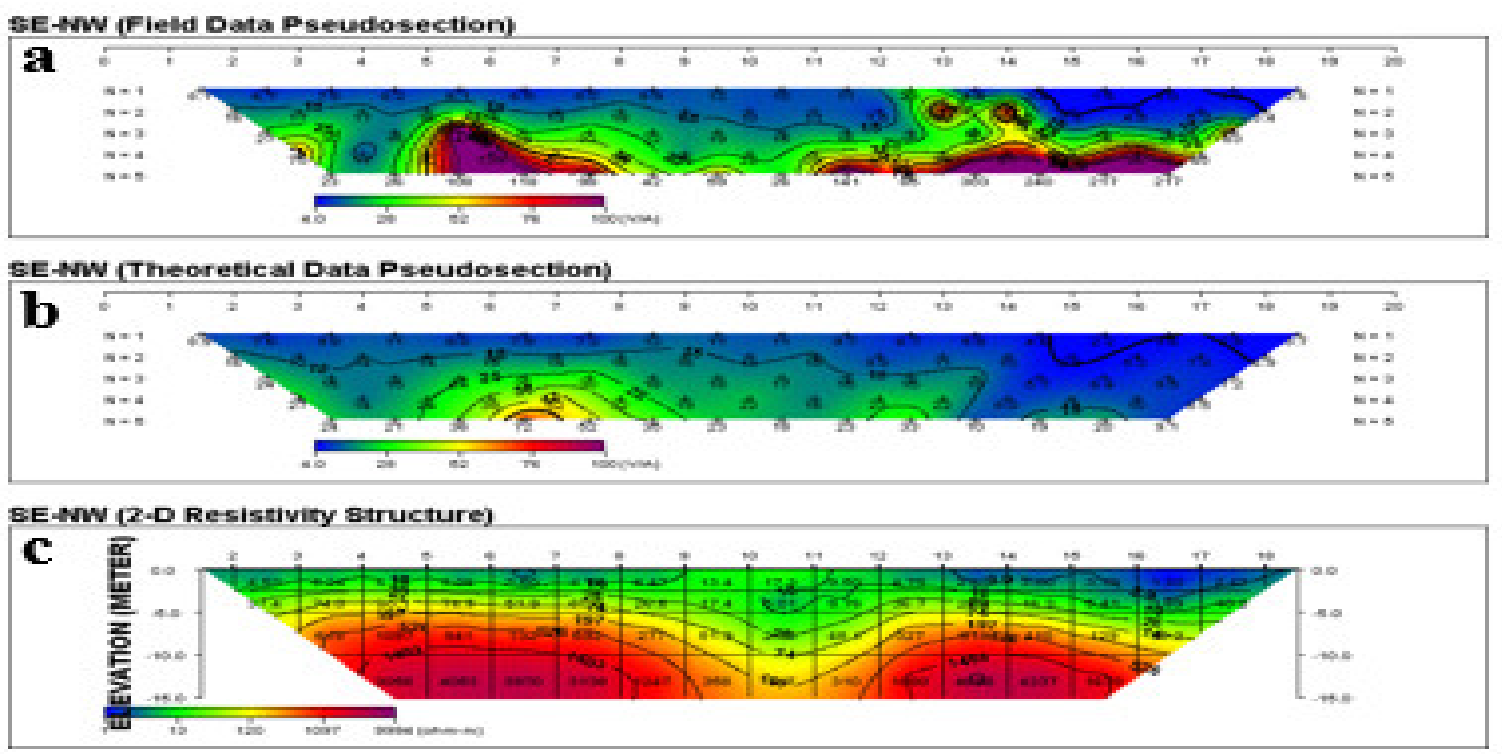

Fig. 7: (a) Field Data Pseudosection (b) Theoretical Data Pseudosection and (c) 2-D Resistivity Structure along Traverse (TR 2).

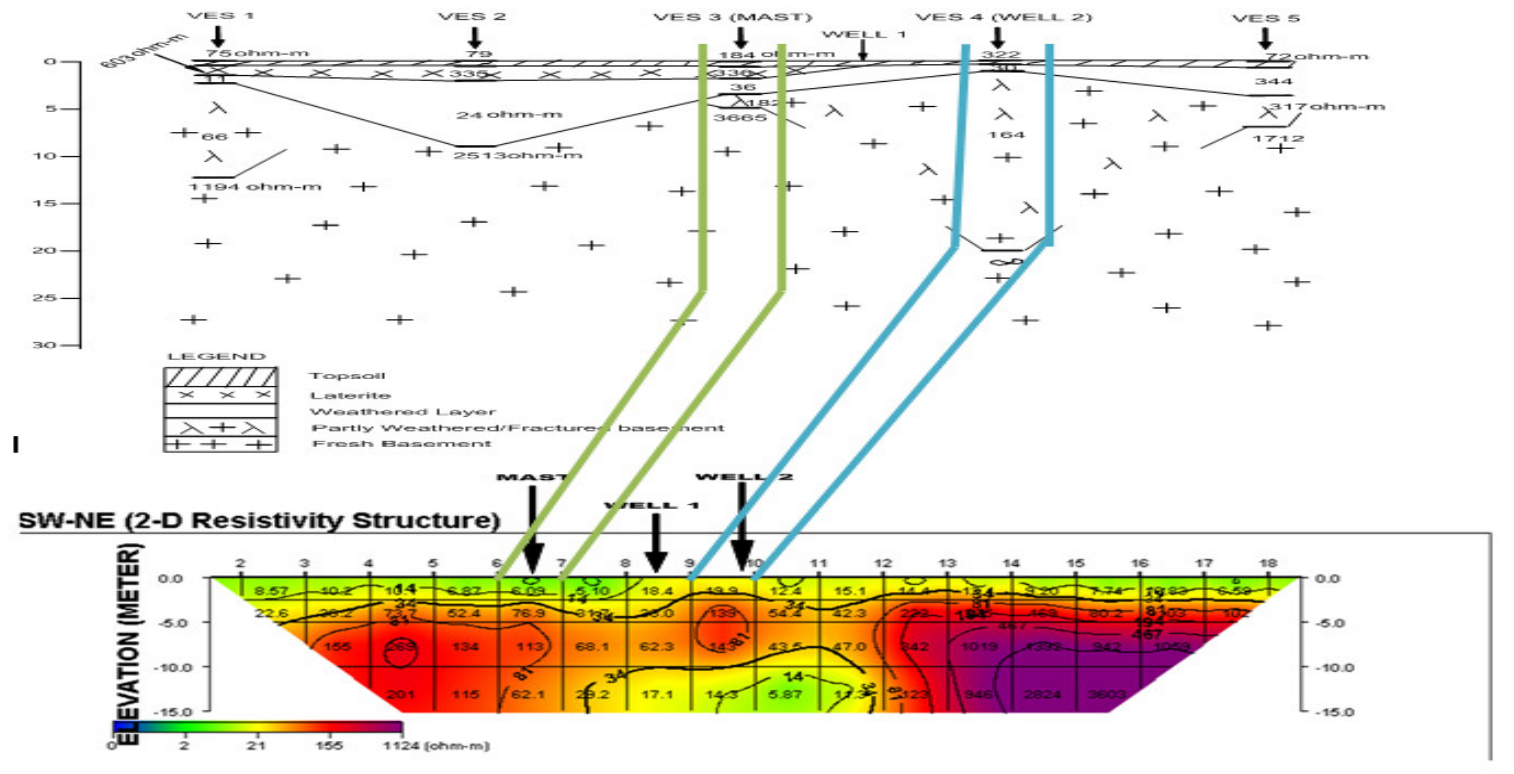

Fig. 8: Correlation of Geoelectric section and 2D resistivity image along TR1

\section{Conclusion}

Geophysical evaluation of groundwater vulnerability was carried out at Adebayo, Ado-Ekiti, Ekiti State, southwestern Nigeria, employing the electrical resistivity method. Four to Five geologic layers were delineated including the topsoil, laterite, weathered layer, fractured, and the fresh basement. The weathered layer and fractured basement constitute the aquifer units in the area.

It was discovered that the low resistivity value from the 2-D resistivity structure of Well 1 may be a result of the clayey nature of the weathered layer and the overlain lateritic layer which serves as the protective membrane thereby protecting the seepage of the pollutant directly into the well 1 . The migration path of the contaminant is towards the southwestern region of the study area. Well 2 which is deeper than well 1 (about $12 \mathrm{~m}$ ) and has a high resistivity value from the 2-D resistivity structure was drilled into the fractured basement. Well 2 contains more traces of the contaminants than Well 1 which was drilled into a shallow portion of the weathered layer. The fracture basement in the study area serves as a conduit to the migration of the contaminant into the Well.

\section{Declaration of Conflict of Interests}

The authors declare no conflict of interests.

\section{Authors' Contributions}

Conception: [00]

Design: [00, TF, BO, JO, AO]

Execution: [00, TF, BO, JO, AO] 
Interpretation: [00, $\mathrm{JO}, \mathrm{AO}]$

Writing the paper: $[00, \mathrm{TF}, \mathrm{BO}, \mathrm{JO}, \mathrm{AO}]$

\section{References}

Adagunodo, T., Sunmonu, L.A., 2012, Geoelectric assessment of groundwater prospect and vulnerability of overburden aquifers at Adumasun area, Oniye, Southwestern Nigeria. Scholars Research Library Archives of Applied Science Research, 4(5):2077 - 2089.

Adelusi A.O., 2009, Aquifer mapping and assessment of its risk using electrical resistivity sounding technique in Akure metropolis, southwestern, Nigeria. Nigeria journal of pure and applied physics, 4:65-73.

Ademilua, O. L., Eluwole, A. B., 2013, Hydrogeophysical Evaluation of the Groundwater Potential of Afe Babalola University Ado-Ekiti, Southwestern Nigeria. Journal of Emerging Trends in Engineering and Applied Sciences, 4(1), 77-83.

Adiat, K.A.N., Olayanju, G.M., Omosuyi, G.O, Ako, B.D., 2009, Electromagnetic profiling and electrical resistivity soundings in groundwater investigation of a typical basement complex - a case study of Oda town Southwestern Nigeria. Ozean Journal of Social Sciences, 2(4):333 - 359.

Aduojo, A.A., Adebowale, A.E., Uchegbulam, O., 2020, Modeling groundwater total dissolved solid from derived electromagnetic data using multiple linear regression analysis: a case study of groundwater contamination. Model. Earth Syst. Environ. 6, 18631875. doi.org/10.1007/s40808 - 020 - 00796-9

Agyare, A., Anornu, G.K., Kabo-bah, A.T., 2017, Assessing the vulnerability of aquifer systems in the Volta river basin: a case-study on Afram Plains, Ghana. Model Earth Syst Environ 3:1141-1159. doi.org/10.1007/s4080 8-017-0363-3

Akinlalu, AA., Adegbuyiro, A., Adiat, K.A.N., Akeredolu, B.E., Lateef, W.Y., 2017, Application of multi-criteria Decision Analysis in Prediction of Groundwater Resources Potential: A Case of Oke-Ana, Ilesa Area, Southwestern, Nigeria. NRIAG Journal of Astronomy and Geophysics, 6:182 - 200.

Ako, B.D., Ajayi, T.R., Arubayi, J.B., Enu, E.I., 2005, The groundwater and its occurrence in the coastal plains sands and alluvial deposits of parts of Lagos State. Nigeria Water Resources, 16:7-17.

Amosun, J.O., Olayanju, G.M., Sanuade, O.A., Fagbemigun, T., 2018, Preliminary geophysical investigation for road construction using integrated methods. RMZ - M\&G. 65 :199-206. DOI 10.2478/rmzmag2018-0017

Bose, K.N., Chatterjee, D., Sen, A.K., 1973, Electrical resistivity surveys for groundwater in the Aurangabad Subdivision, Gaya District, Bihar, Indian, 171-181.

Datta, A., Gaikwad, H., Kadam, A., Umrikar, B.N., 2020, Evaluation of groundwater prolific zones in the unconfined basaltic aquifers of Western India using geospatial modeling and MIF technique. Model. Earth Syst. Environ. 6, 1807 - 1821. doi.org/10.1007/s40808 - 020 00791-0

Egbueri, J.C., Mgbenu, C.N., Chukwu, C.N., 2019, Investigating the hydrogeochemical processes and quality of water resources in Ojoto and environs using integrated classical methods. Model. Earth Syst. Environ. 5, 1443 - 1461. doi.org/10.1007/s40808 - 019 - 00613-y

Fajana, A.O., 2020, Integrated geophysical investigation of aquifer and its groundwater potential in phases 1 and 2, federal university OyeEkiti South-western basement complex of Nigeria. Model. Earth Syst. Environ. 6, 1725 - 1725. doi.org/10.1007/s40808 - 020 - 00785-y

Khan, M.J., Shah, B.A., Nasir, B., 2020, Groundwater quality assessment for drinking purpose: a case study from Sindh Industrial Trading Estate, Karachi, Pakistan. Model. Earth Syst. Environ. 6, 263 - 272. doi.org/10.1007/s40808-019-00676-x

Mogaji, K.A., 2016, Combining geophysical techniques and multicriteria GIS-based application modeling approach for groundwater potential assessment in southwestern Nigeria. Environmental Earth Sciences,75, 1181. doi.org/10.1007/s12665-0165897.

Mogaji, K.A., Lim, H.S., Abdullar, K., 2014, Modeling groundwater vulnerability to pollution using Optimized DRASTIC model. IOP Conf. Series: Earth and Environmental Science, 20, 012002.

Mohamed, S.E.J., Shaharin, I., Wan, N.A.S., Puziah, A.L., 2013, Groundwater resources assessment using integrated geophysical techniques in the southwestern region of Peninsular, Malaysia. Arabian Journal of Geosciences, 6(11):4129-4144.

Obiora, D.N., Ajala, A.E., Ibuot, J.C., 2015, Evaluation of aquifer protective capacity of overburden unit and soil corrosivity in Makurdi, Benue State, Nigeria, using electrical resistivity method. Journal of Earth System Science, 124(1): 125-135.

Oguama, B.E., Ibuot, J.C., Obiora, D.N., Aka, M.U., 2019, Geophysical investigation of groundwater potential, aquifer parameters, and vulnerability: a case study of Enugu State College of Education (Technical). Model Earth Syst Environ 5:11231133.https://doi.org/10.1007/s4080 8-019-00595-x

Oladapo, M.I., Mohammed, M.Z., Adeoye, O.O., Adetola, B.A., 2004, Geoelectric Investigation of the Ondo State Housing Corporation Estate, Ijapo, Akure, Southwestern Nigeria. Journal of Mining and Geology, 40:41 - 48.

Oladimeji, L.A., Oluwaseun, O.S., 2013, Evaluation of aquifer protective capacity of groundwater resources within Afe Babalola University, Ado-Ekiti, Southwestern Nigeria. Transitional Journal of Science and Technology, 3(6):1-16.

Olaseeni, O.G., Oladapo, M.I., Olayanju, G.M., 2020, Vulnerability assessment of an aquifer in the basement complex terrain of Nigeria using 'LAHBUD' model. Model Earth Syst Environ.doi.org/10.1007/s40808-020-00912-9.

Olaseeni, O.G., Oladapo, M.I, Olayanju G.M, Dada O.J, Oyebamiji A.R., 2019, Groundwater Vulnerability Assessment using Electrical Resistivity Method in the Northern part of Ado-Ekiti, Southwestern Nigeria. In: IOP Conference Series: Journal of Physics, 1299, 012068. doi.org/10.1088/1742.6596

Omosuyi, G.O., 2010, Geoelectric assessment of groundwater prospect and vulnerability of overburden aquifers at Idanre, south-western Nigeria. Ocean Journal of Applied Sciences, 3(1):19 - 28. 
Omosuyi, G.O., Adegoke, A,O., Adelusi, A., 2008, Interpretation of electromagnetic and geoelectric sounding data for groundwater resources around Obanla-Obakekere, near Akure, Southwestern Nigeria. Pacific J. Sci. Technol., 9(2):509 - 525.

Omotola, O,O., Oladapo, M.I, Akintorinwa, O.J., 2020, Modeling assessment of groundwater vulnerability to contamination risk in a typical basement terrain case of vulnerability techniques application comparison study. Model Earth Syst Environ 6:1253-1280. doi.org/10.1007/s4080 8-020-00720 -1

Satpatty, B.N., Kanugo, B.N., 1976, Groundwater exploration in hard rock terrain, a Case study. Geophysical Prospecting, 24(4):725 - 736.
Telford, W.M., Geldart, L.P., Sheriff, R.E., 1990, Applied Geophysics, 2nd Edition: Cambridge. Cambridge University Press, U.K.

Todd, D.K., 2004, Groundwater Hydrology, John Wiley \& Sons, New York. 